\title{
DESAIN DAN VALIDASI LEMBAR KERJA PESERTA DIDIK BERDASARKAN KERAGAMAN MAKROINVERTEBRATA DI SUNGAI KETAHUN
}

\author{
Winda Wahyuni ${ }^{1 *}$, Abdul Rahman Singkam ${ }^{1}$, Kasrina ${ }^{1}$ \\ ${ }^{1}$ Program Studi Pendidikan Biologi, Fakultas Keguruan dan Ilmu Pendidikan, Universitas Bengkulu \\ Email: windaduta2@gmail.com
}

\begin{abstract}
Abstrak
Penelitian ini bertujuan untuk mengetahui kelayakan Lembar Kerja Peserta Didik (LKPD) yang dikembangkan berdasarkan keragaman makroinvertebrata di Sungai Ketahun Bengkulu Utara. Subjek penelitian ini adalah peserta didik kelas X Sekolah Menengah Atas (SMA) Negeri 12 Bengkulu Utara. Instrumen yang digunakan adalah lembar angket (kuisioner) untuk tiga orang validator (dua orang Dosen Program Studi Pendidikan Biologi dan guru Biologi SMA kelas X), dan lembar keterbacaan untuk peserta didik. Berdasarkan hasil validasi oleh tiga validator, LKPD yang disusun sangat layak digunakan dengan nilai rata-rata $84,7 \%$. Desain LKPD juga dinyatakan layak dalam uji keterbacaan oleh 30 orang peserta didik di SMA Negeri 12 Bengkulu Utara dengan nilai rata-rata 89\%. Hasil validasi dan uji keterbacaan ini menunjukkan bahwa LKPD yang dikembangkan layak untuk digunakan sebagai bahan ajar pada materi keanekaragaman hayati kelas $X$ tingkat SMA.
\end{abstract}

Kata kunci: Pengembangan LKPD, Keragaman, Makroinvertebrata

\begin{abstract}
This study aims to determine the feasibility of Student Worksheets (LKPD) developed based on macroinvertebrate diversity in the Ketahun River in North Bengkulu. The subjects of this study were students of class $X$ at SMA Negeri 12 North Bengkulu. The instrument used was a questionnaire sheet (questionnaire) for three validators (two lecturers of Biology Education Study Program and a biology teacher from senior high school, and readability sheets for students. Based on the results of the three validators, the compiled LKPD is very feasible to be used with $84.7 \%$ as an average value. The designed LKPD was also declared as feasible in the readability test by 30 students in SMA Negeri 12 Bengkulu Utara with an average score of $89 \%$. The results of this validation and legibility test show that the LKPD was ordered to be used as the teaching material of grade $X$ high school level biodiversity.
\end{abstract}

Keywords: Development of LKPD, Diversity, Macroinvertebrates

\section{PENDAHULUAN}

Sungai Ketahun sebagai sungai terbesar di Bengkulu memiliki Daerah Aliran Sungai (DAS) seluas 2.405.45 km2. Aliran sungai ini memiliki tujuh sub DAS yaitu ketahun hulu, ketahun tengah, ketahun hilir, lelangi hulu, lelangi tengah, lelangi hilir, suwoh dan santan (BPDASHL, 2016). Sungai Ketahun merupakan salah satu sungai di Bengkulu yang memiliki potensi lokal keanekaragaman hayati yang belum banyak diteliti. Salah satu keanekaragaman hayati yang terdapat di DAS Ketahun adalah makroinvertebrata.

Makroinvertebrata merupakan jenis hewan invertebrata yang dapat dilihat tanpa bantuan mikroskop, tidak memiliki tulang belakang yang hampir menempati setiap habitat di muka bumi (Campbell, 2008). Pada umumnya makroinvertebrata hidup melekat pada substrat pada kedalaman air kurang dari 0.5 meter (Putro, 
2014).

Penelitian Wahyuni (2019) menemukan 33 jenis makroinvertebrata yang terdiri dari 29 famili (Prosiding Semirata BKS PTN Wilayah Barat Bidang MIPA). Keragaman makroinvertebrata di Sungai Ketahun dapat dijadikan sebagai sumber belajar untuk meningkatkan pembelajaran peserta didik terhadap materi keanekaragaman hayati di Sekolah Menengah Atas (SMA) kelas X. Selain itu, sumber belajar juga dapat membantu guru dalam malaksanakan kegiatan belajar mengajar di kelas. Salah satu sumber belajar yang dapat dikembangkan adalah Lembar Kerja Peserta Didik (LKPD) (Nurdin, 2016).

LKPD merupakan salah satu bahan ajar yang didalamnya berisi lembar kerja yang dapat menuntun peserta didik untuk belajar lebih aktif (Dewi, 2016). Menurut Asnaini (2016) pengembangan LKPD sangat diperlukan dalam dunia pendidikan yang dapat mempermudah pencapaian tujuan pembelajaran yang diharapkan. LKPD dapat dikembangkan oleh guru sebagai fasilitator untuk menunjang pembelajaran di dalam kelas (Widjajanti, 2008). Selain itu, LKPD dapat digunakan oleh guru dengan mengacu pada Kompetensi Inti (KI) dan Kompetensi Dasar (KD) (Prastowo, 2015).

Pembelajaran biologi SMA di Bengkulu khususnya Kecamatan Ulok Kupai telah menggunakan sumber belajar berupa LKPD, namun sumber belajar tersebut belum memanfaatkan potensi lokal yang ada di lingkungan sekitar. Berdasarkan wawancara peneliti kepada salah seorang guru biologi di SMA Negeri 12 Bengkulu Utara Kecamatan Ulok Kupai didapatkan informasi bahwa sekolah tersebut telah menggunakan sumber belajar berupa LKPD dari penerbit. Namun LKPD penerbit ini belum mengangkat potensi lokal yang ada di lingkungan peserta didik. Oleh karena itu, dilakukan pengembangan LKPD berdasarkan keragaman makroinvertebrata di Sungai Ketahun, dengan harapan dapat dijadikan sebagai sumber belajar peserta didik pada materi keanekaragaman hayati kelas X SMA.

\section{METODE}

Jenis penelitian yang digunakan adalah Penelitian dan Pengembangan (Reseach and Development). Rancangan penelitian mengadopsi dari langkah-langkah model pengembangan Sugiyono (2009). Penelitian dilaksanakan pada bulan Mei 2019 di SMA Negeri 12 Bengkulu Utara. Validasi untuk uji kelayakan dalam penelitian ini adalah tiga orang validator yang terdiri dari dua orang dosen Pendidikan Biologi Universitas Bengkulu dan satu orang guru Biologi SMA Negeri 12 Bengkulu Utara. Sedangkan subjek uji keterbacaan dalam penelitian ini adalah siswa kelas X SMA Negeri 12 Bengkulu Utara sebanyak 30 orang. Teknik pengumpulan data dalam penelitian ini menggunakan lembar angket (kuesioner) yang terdiri atas angket uji kelayakan untuk tiga orang validator (ahli materi, ahli media dan guru biologi SMA) dan angket uji keterbacaan untuk peserta didik.

Data uji validasi dan uji keterbacaan LKPD dianalisis secara deskriptif kuantitatif. Angka hasil uji yang diperoleh diubah ke dalam persentase kelayakan dengan menggunakan rumus:

$\frac{\text { Jumlah skor lembar validasi }}{\text { skor maksimal }} X 100 \%$

(Riduwan, 2013). 
Hasil perhitungan persentase kelayakan dan keterbacaan ini kemudian diinterpretasikan ke dalam kategori kualitatif. Interpretasi skor kelayakan LKPD dan keterbacaan dapat dilihat pada Tabel 1.

Tabel 1. Intepretasi skor kelayakan LKPD dan Keterbacaan

\begin{tabular}{cc}
\hline Skor Rata-rata & Kriteria Respon \\
\hline $0-20 \%$ & Sangat Tidak Layak \\
$21-40 \%$ & Tidak Layak \\
$41-60 \%$ & Cukup Layak \\
$61-80 \%$ & Layak \\
$81-100 \%$ & Sangat Layak
\end{tabular}

(Riduwan, 2013).

\section{HASIL DAN PEMBAHASAN}

Secara keseluruhan desain LKPD yang disusun dikategorikan sangat layak oleh tiga orang validator dengan nilai rata-rata 84,7\%. Hasil persentase validasi dapat dilihat pada Tabel 2. Hal ini berarti LKPD yang telah dikembangkan sudah memenuhi kriteria LKPD dan layak digunakan sebagai bahan ajar dalam materi keanekaragaman hayati. LKPD yang dikembangkan mengadopsi kriteria menurut Katriani (2014) yaitu: topik kegiatan sesuai dengan $K D$, tujuan pembelajaran sesuai dengan $K D$, berisi tabel hasil pengamatan dan pertanyaan serta kesimpulan.

Hasil validasi berupa saran dari validator juga telah dijadikan acuan perbaikan LKPD. Widarmayanti (2015) menyebutkan bahwa yang diharapkan dari validasi adalah saran dan perbaikan LKPD. Prastowo (2011) menyebutkan bahwa "Suatu bahan ajar sebelum diterapkan ke dalam kelas, terlebih dahulu harus disusun secara sistematis dan teratur agar bahan ajar tersebut tidak membuat bingung, sehingga menjadi bahan ajar yang menarik bagi peserta didik yang membacanya".
Tabel 2. Persentase Validasi Oleh Validator

\begin{tabular}{clcc}
\hline No & \multicolumn{1}{c}{ Validator } & $\begin{array}{c}\text { Rata-rata } \\
\text { persentase }\end{array}$ & Kriteria \\
\hline 1. & $\begin{array}{l}\text { Validator 1 (Ahli } \\
\text { Materi) }\end{array}$ & $85,7 \%$ & $\begin{array}{c}\text { Sangat } \\
\text { Layak } \\
\text { Layak }\end{array}$ \\
2. & $\begin{array}{l}\text { Validator 2 (Ahli } \\
\text { Media) }\end{array}$ & $80 \%$ & Sangat \\
3. & $\begin{array}{l}\text { Validator } \\
\text { (Guru Biologi } \\
\text { SMA Kelas X) }\end{array}$ & $88,5 \%$ & Layak \\
\hline & Rata-rata & $84,7 \%$ & $\begin{array}{l}\text { Sangat } \\
\text { Layak }\end{array}$ \\
\hline
\end{tabular}

Beberapa saran dan perbaikan dari ketiga validator dapat dilihat pada Tabel 3.

Table 3. Saran dan Perbaikan Dari Validator

\begin{tabular}{cl}
\hline No & \multicolumn{1}{c}{ Saran dan perbaikan dari validator } \\
\hline 1 & $\begin{array}{l}\text { Kompetensi Dasar (KD) } 4.2 \text { harus dicantumkan } \\
\text { dalam LKPD. }\end{array}$ \\
2. Penambahan gambar pada materi pokok. \\
3. Perbaikan background pada tabel \\
pengamatan. \\
4. Susunan pertanyaan pada LKPD disesuaikan \\
dengan tujuan
\end{tabular}

Berdasarkan hasil validasi yang telah dilakukan oleh tiga validator, maka dilakukan revisi terhadap desain LKPD. LKPD yang disusun telah mengikuti panduan penyusunan (Prastowo, 2015) yang terdiri atas halaman awal (cover), tujuan pembelajaran, ringkasan materi, alat dan bahan, prosedur kerja, tabel pengamatan, pertanyaan-pertanyaan yang harus dijawab oleh peserta didik dan simpulan. Adapun beberapa revisi yang dilakukan dapat dilihat pada Gambar 1, Gambar 2, Gambar 3 dan Gambar 4. 


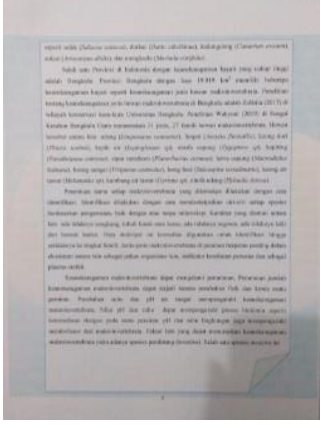

Sebelum direvisi

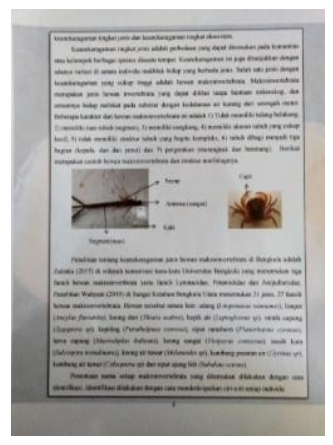

Sesudah direvisi
Gambar 2. Materi pokok sebelum dan sesudah revisi

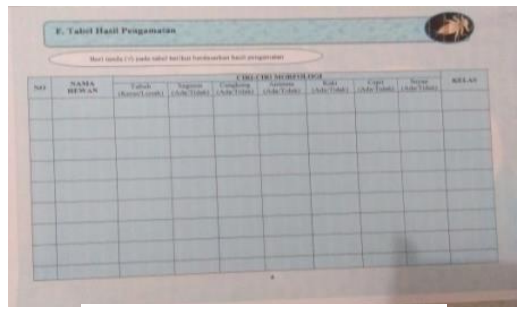

Sebelum direvisi

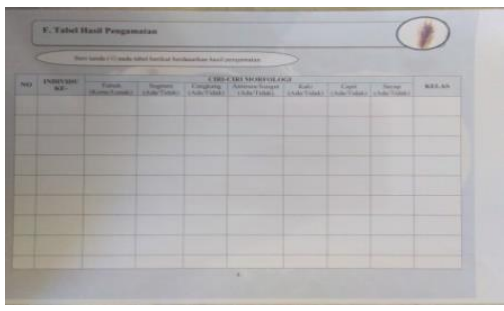

Sesudah direvisi

Gambar 3. Pemilihan background pada tabel pengamatan sebelum dan sesudah revisi.

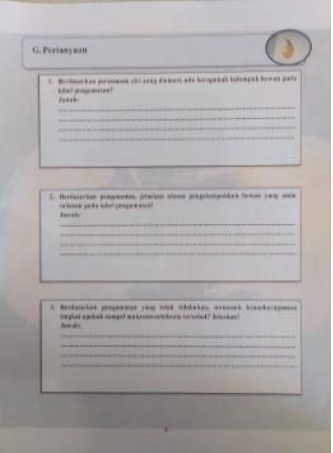

Sebelum direvisi

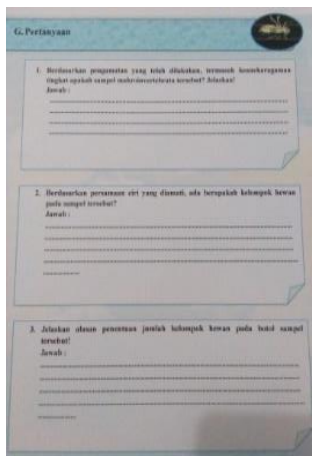

Sesudah direvisi
Gambar 4. Susunan pertanyaan pada LKPD sebelum dan sesudah revisi
Setelah desain LKPD direvisi kemudian dilakukan uji keterbacaan pada 30 orang peserta didik kelas X SMA Negeri 12 Bengkulu Utara. Uji keterbacaan dilakukan untuk melihat apakah LKPD yang telah dikembangkan sudah layak dan baik untuk digunakan oleh peserta didik dalam pembelajaran. Hasil uji keterbacaan menunjukkan bahwa LKPD yang disusun dinilai sangat layak oleh peserta didik dengan hasil persentase $89 \%$. Hasil uji keterbacaan oleh peserta didik kelas X SMA Negeri 12 Bengkulu Utara dapat dilihat pada Tabel 3. Hal ini sesuai dengan kriteria persentase keterbacaan jika diperoleh skor $>80 \%$ maka termasuk kedalam kriteria sangat layak.

LKPD yang telah dikembangkan dari hasil penelitian keragaman makroinvertebrata di Sungai Ketahun dapat digunakan sebagai bahan ajar pada materi keanekaragaman hayati di SMA kelas $X$, karena telah melewati uji validasi kelayakan dan uji keterbacaan. Sebagian besar pendapat yang diberikan oleh peserta didik terhadap LKPD yang telah dikembangkan ini adalah LKPD yang didesain memiliki cover yang menarik, materi yang jelas dan menarik, dan isi LKPD mudah untuk dipahami. Namun ada beberapa saran dari beberapa peserta didik yang dijadikan sebagai perbaikan dalam LKPD.

Saran dan masukan dari peserta didik terhadap LKPD adalah tentang penyajian gambar dalam LKPD dan penggunaan bahasa yang lebih mudah dimengerti, contohnya seperti kata "diversitas" diganti dengan "keragaman", makroinvertebrata diganti dengan "invertebrata". Hal ini sesuai dengan Prastowo (2010) bahwa LKPD hendaknya didesain menarik dengan menggunakan bahasa yang sesuai dengan tingkat perkembangan peserta didik. 
Penelitian sebelumnya Fajri (2018) tentang kelayakan LKPD pada materi keanekaragaman hayati di kelas X MIPA2 SMAN 09 Kota Bengkulu mendapatkan respon yang sangat baik oleh peserta didik dengan nilai rata-rata $80 \%$. Respon peserta didik terhadap LKPD yang dikembangkan menunjukkan bahwa pembelajaran dengan bahan ajar LKPD berbasis penelitian dapat memberikan hal baru bagi peserta didik dalam pembelajaran di kelas. Asnaini (2016) juga menjelaskan bahwa LKPD hasil pengembangan dapat didesain sesuai dengan keadaan peserta didik.

Tabel 3. Hasil Uji Keterbacaan Oleh Peserta Didik Kelas X SMA Negeri 12 Bengkulu Utara

\begin{tabular}{|c|c|c|c|}
\hline No & Aspek Penilaian & $\begin{array}{l}\text { Persentase } \\
\text { Setuju }\end{array}$ & Kriteria Kualitatif \\
\hline 1. & $\begin{array}{l}\text { Struktur LKPD disusun secara sistematis/urut } \\
\text { sehingga saya mudah memahami }\end{array}$ & $100 \%$ & Sangat Layak \\
\hline 2. & $\begin{array}{l}\text { Kegiatan yang disajikan dalam LKPD mempunyai } \\
\text { tujuan yang jelas }\end{array}$ & $100 \%$ & Sangat Layak \\
\hline 3. & $\begin{array}{l}\text { Kegiatan yang disajikan dalam LKPD dapat } \\
\text { merangsang keingintahuan saya }\end{array}$ & $100 \%$ & Sangat Layak \\
\hline 4. & $\begin{array}{l}\text { Penampilan LKPD membuat saya tertarik untuk } \\
\text { mengerjakannya }\end{array}$ & $70 \%$ & Layak \\
\hline 5. & $\begin{array}{l}\text { Penyajian LKPD dilengkapi dengan gambar dan } \\
\text { ilustrasi sehingga membantu saya memahami } \\
\text { materi }\end{array}$ & $70 \%$ & Layak \\
\hline 6. & $\begin{array}{l}\text { Susunan kalimat yang disajikan jelas, sederhana, } \\
\text { dan mudah saya mengerti }\end{array}$ & $100 \%$ & Sangat Layak \\
\hline 7. & Bahasa yang digunakan dapat saya pahami & $90 \%$ & Sangat Layak \\
\hline 8. & $\begin{array}{l}\text { Bahasa yang disajikan sesuai dengan tingkat } \\
\text { perkembangan saya }\end{array}$ & $80 \%$ & Layak \\
\hline 9 & $\begin{array}{l}\text { Saya mudah memahami petunjuk/arahan dalam } \\
\text { LKPD }\end{array}$ & $100 \%$ & Sangat Layak \\
\hline \multirow[t]{2}{*}{10.} & $\begin{array}{l}\text { Pertanyaan yang disajikan dalam LKPD mudah saya } \\
\text { pahami }\end{array}$ & $80 \%$ & Layak \\
\hline & Rata-rata persentase & $89 \%$ & Sangat Layak \\
\hline
\end{tabular}

LKPD yang dikembangkan berdasarkan pemanfaatan potensi lokal sehingga dapat meningkatkan pengetahuan peserta didik terhadap keanekaragaman hayati khususnya keragaman makroinvertebrata yang ada di lingkungan sekitar yang belum diketahui oleh peserta didik. Sikap keingintahuan merupakan salah satu aspek ilmiah yang seharusnya dimiliki oleh peserta didik yang belum diterapkan skeseluruhan (Sari, 2016). Sikap ilmiah merupakan salah satu karakteristik pembelajaran biologi yang terdapat di sekolah (Tasiwan, dkk 2014).

Pembelajaran berbahan lokal akan lebih kontekstual dengan lingkungan peserta didik, sehingga membuat peserta didik tertarik untuk mempelajarinya. Handini (2018) menyatakan bahwa suatu bahan ajar yang dikembangkan berdasarkan karakteristik dan kearifan lokal lebih memberikan kesan yang nyata dalam pembelajaran. Pemanfaatan lingkungan juga dapat mengembangkan sejumlah keterampilan, seperti mengamati, mencatat, merumuskan pertanyaan, 
berhipotesis dan mengklasifikasikan (Uno dan Mohamad, 2014). Karsli (2009) juga menjelaskan bahwa penggunaan LKPD berbasis lingkungan dapat meningkatkan penguasaan konsep pada peserta didik.

\section{PENUTUP}

\section{Simpulan}

Hasil pengembangan Lembar Kerja Peserta Didik (LKPD) yang disusun berdasarkan keragaman makroinvertebrata di Sungai Ketahun dinyatakan sangat layak untuk diujicobakan kepada peserta didik oleh tiga orang validator dengan nilai ratarata $84,7 \%$. Hasil uji keterbacaan juga dinyatakan sangat layak oleh peserta didik dengan nilai rata-rata $89 \%$.

\section{Saran}

Diharapkan untuk penelitian selanjutnya dapat mengimplementasikan LKPD yang telah didesain pada pembelajaran di sekolah kelas X SMA materi keanekaragaman hayati.

\section{DAFTAR PUSTAKA}

Asnaini, Adlim dan Mahidin. 2016. Pengembangan LKPD Berbasis Pendekatan Scientific untuk Meningkatkan Hasil Belajar dan Aktivitas Peserta Didik Pada Materi Larutan Penyangga. Jurnal Pendidikan Sains Indonesia 4 (2): 191-201. (Online).

(http://jurnal.unsyiah.ac.id/JPSI/articl e/view/6597), Diakses pada tanggal 20 Juli 2019.

BPDASHL. 2016. Peta DAS Ketahun_Wilayah Kerja BPDASHL Ketahun (https://www.sipdas.menhhk.go.id diakses tanggal 11 November 2018)
Campbell, Reece, et al. 2008. Biologi. Edisi kedelapan Jilid 1. Jakarta. Erlangga

Dewi, B.M. 2016. Pengembangan LKPD Pencemaran Air Berpendekatan Authentic Inquiry Learning Untuk Meningkatkan Keingintahuan Dan Pemecahan Masalah SMP Kelas VII. (Skripsi). Yogyakarta: Universitas Negeri Yogyakarta.

Fajri, Aziza. 2018. Pengembangan Lembar Kerja Peserta Didik Materi Vertebrata Kelas X Berdasarkan Inventarisasi Ikan Laut. Jurnal Pendidikan dan Pembelajaran Biologi 2 (2): 52-57. (Online).

(https://ejournal.unib.ac.id/index.php /jppb/article/view/6804), Diakses pada tanggal 19 Juli 2019.

Handini, M. N. 2018. Studi Etnobotani Tumbuhan Obat Suku Serawai Sebagai Pengembangan Handout Biologi Kelas X SMA. Diklabio 2 (2): 43-53. (Online). (https://ejournal.unib.ac.id/index.php /jppb/article/view/6802), Diakses pada tanggal 20 Juli 2019.

Karsli, F., dan Sahim., C. 2009. Developing Worksheet Based on Science Process Skills Factors Affecting Solubility. Jurnal Asia-Pacific Forum on Science Learning and Teaching 10 (1): 121130. (Online). (http://ijpsat.ijshtjournals.org/index.php/ijpsat/article/ view/545), Diakses pada tanggal 21 Juli 2019.

Katriani, L. 2014. Pengembangan Lembar Kerja Peserta Didik (LKPD). 
Yogyakarta: Universitas Negeri Yogyakarta.

Nurdin, S. 2016. Kurikulum dan Pembelajaran. Jakarta: Rajawali Press.

Prastowo, A. 2010. Panduan Kreatif Membuat Bahan Ajar Inovatif. Jogjakarta: Diva Press.

Prastowo, A. 2011. Panduan Kreatif Membuat Bahan Ajar Inovatif. Yogyakarta: Diva Press.

Prastowo, A. 2015. Panduan Kreatif Membuat Bahan Ajar. Yogyakarta: Diva Press.

Putro, P. D. 2014. Metode Sampling Penelitian Makrobenhos dan Aplikasinya. Yogyakarta: Graha ilmu.

Riduwan. 2013. Skala Pengukuran Variabelvariabel Penelitian. Bandung: ALFABETA.

Sari, A. P. P dan Lepiyanto, Agil. 2016. Pengembangan Lembar Kerja Peserta Didik (LKPD) Berbasis Scientific Approach Siswa SMA Kelas X Pada Materi Fungi. Jurnal Pendidikan Biologi 7 (1): 41-49. (Onlie). (http://ojs.fkip.ummetro.ac.id/index.p hp/biologi/article/view/489), Diakses pada tanggal 22 Juli 2019.

Sugiyono. 2009. Metode Penelitian Pendidikan (Pendekatan Kuantitatif, Kualitatif dan R\&D). Bandung: Alfabeta.

Tasiwan, S. E., Nugroho dan Hartono. 2014. Analisis Tingkat Motivasi Siswa Dalam Pembelajaran IPA Model Advance Organizer Berbasis Proyek. Jurnal Pendidikan IPA Indonesia 3 (1) : 43-50. (Online). (https://www.researchgate.net/public ation/307730466 Analisis Tingkat M otivasi Siswa Dalam Pembelajaran I PA Model Advance Organizer Berba sis Proyek), Diakses pada tanggal 20 Juli 2019).

Uno, H.B., N. Mohamad. 2014. Belajar Dengan Pendekatan PAILKEM. Jakarta: Bumi Aksara.

Wahyuni, W., Kasrina., dan Abdul. R. 2019. Diversitas Dan Kelimpahan Makroinvertebrata Di Sungai Ketahun Kabupaten Bengkulu Utara. Prosiding Semirata BKS PTN Wilayah Barat Bidang MIPA. Bengkulu: Universitas Bengkulu.

Widarmayanti, R. P., Susantini, E., Ambarwati, R. 2015. Profil Validitas LKS Berbasis Keterampilan Proses Pada Subpokok Bahasan Invertebrata Untuk Kelas X SMA. Jurnal Bioedu. 4 (1): $\quad$ 2302-9528. (Online). (https://jurnalmahasiswa.unesa.ac.id/ index.php/bioedu/article/view/10931 ), Diakses pada tanggal 21 Juli 2019.

Widjajanti, E. 2008. Kualitas Lembar Kerja Siswa. Jurnal Pendidikan FMIPA Universitas Negeri Yogyakarta. 